\title{
Małgorzata Olejarz (red.), „Dyskursy Młodych Andragogów”, t. 14, Wyd. Uniwersytetu Zielonogórskiego, Zielona Góra 2013
}

Czternasty tom czasopisma „Dyskursy Młodych Andragogów” zawiera teksty młodych naukowców reprezentujących środowiska z Polski i zagranicy, z zakresu takich dyscyplin jak: andragogika, pedagogika społeczna, poradoznawstwo, socjologia. Teksty zawarte w publikacji są prezentacją zagadnień, problemów, jakimi zajmują się obecnie badacze szeroko rozumianej edukacji dorosłych. Problematyka artykułów pokazuje różnorodność i wielokierunkowość rozwoju środowiska młodych naukowców.

Struktura recenzowanej publikacji została podzielona na trzy działy tematyczne: andragogiczny, poradoznawczy oraz metodologiczny. Dyskurs andragogiczny otwierają teksty poruszające kwestie różnych obszarów społecznego wykluczenia. Anna Bilon w artykule zatytułowanym Od nadziei do zwątpienia - o wspótczesnych kontekstach i mechanizmach wykluczeń społecznych, omawia mechanizmy oraz polityczne, ideologiczne, systemowe i edukacyjne konteksty wykluczenia społecznego. W tekście zostały przedstawione mechanizmy wykluczeń tkwiące u podstaw porządku społecznego, w jakim obecnie żyjemy. Autorka przyjęła punkt widzenia krytyki współczesnej koncepcji rozwoju społecznego. Mechanizmy wykluczeń, które zostały tu przedstawione, są mechanizmami „systemowymi”, co nie oznacza, że zawsze determinują losy jednostek. Z perspektywy przedstawionej krytyki, największym mechanizmem wykluczeń społecznych jest szeroko rozumiany wolny rynek, oparty na zasadzie konkurencji. Rynek ten dzieli świat na znajdujących się w jego centrum i na tych, którzy zmuszeni są żyć na jego peryferiach. Porządek społeczny, oparty na neoliberalizmie, miał przyczynić się do stabilnej sytuacji gospodarczej na świecie i „powszechnej szczęśliwości", jednak okazał się porządkiem wykluczającym i rodzącym nierówności. 
W dużej mierze dotyczy to również polskiej młodzieży, ponieważ, jak wskazuje opublikowany w 2011 roku raport Młodzi 2011, pomimo tego, że jest ona pokoleniem najlepiej wykształconym w całej historii Polski, wciąż doświadcza wielu trudności na rynku pracy. Joanna Łaszyn analizuje w swoim tekście edukację pozaformalną dorosłych Romów w kontekście teorii Nancy Fraser. Wychodząc z założenia, że edukacja (pozaformalna) uznawana jest za jedną z najważniejszych dróg poprawy społecznej pozycji Romów i postrzegana jest jako czynnik mający niwelować niesprawiedliwość ekonomiczną i kulturową, autorka wskazuje jej organizatorów, cele oraz wybrane formy organizacyjne. Rozważania przedstawione w artykule kończy próba ewaluacji jakości wybranych form edukacji pozaformalnej w oparciu o dostępne raporty, wypowiedzi respondentów oraz własne obserwacje autorki. Urszula Dmochowska w tekście Zwalczanie odradzającego się analfabetyzmu - zadania i wyzwanie edukacji dorostych, opisuje współczesne oblicza analfabetyzmu ludzi dorosłych, ze szczególnym uwzględnieniem analfabetyzmu funkcjonalnego, jego przyczyny i społeczne konsekwencje. W niniejszym opracowaniu uwagę skupiono na przedstawieniu rozwiązań niemieckich i brytyjskich w walce $z$ analfabetyzmem. Następny artykuł, autorstwa niemieckiej badaczki Salvany Dietel, dotyczy wartości emocji w zespołowym i jednostkowym doświadczaniu świata, szczególną uwagę koncentrując na znaczeniu emocji $\mathrm{w}$ procesach edukacyjnych. W dyskursie andragogicznym znajdują się także teksty oparte głównie na badaniach własnych autorów. Monika Bartkowiak i Joanna Szłapińska w artykule Doskonalenie zawodowe pracowników w praktyce przedsiębiorstw eksplorują zależność między funkcjonowaniem kadry menedżerskiej a polityką firmy w zakresie szkoleń i rozwoju kadr. Charakterystyka działalności przedsiębiorstw w gospodarce uczącej się oraz zmian zachodzących na rynku usług szkoleniowych stanowi podstawę rozważań teoretycznych. W części poświęconej analizie wyników badań autorki zaprezentowały aktywność edukacyjną pracowników oraz jej ocenę, odnosząc się do systemów szkoleniowo-rozwojowych organizacji. Wyprowadzone na podstawie wyników badań postulaty praktyczne, usprawniające analizowane procesy rozwojowe pracowników, stanowią podsumowanie rozważań zawartych w artykule. Anna Wawrzonek opisuje rolę organizacji pozarządowych w stymulowaniu aktywności zawodowej na terenie społeczności lokalnej, która postrzegana jest współcześnie jako naturalny układ społeczny z punktu widzenia jednostek, w obrębie której przebiega większość aktywności życiowych mieszkańców związanych z pracą zawodową, życiem rodzinnym, kulturowym, religijnym i politycznym. Zaprezentowane w artykule kierunki działań badanych organizacji pozarządowych oraz 
oczekiwania liderów względem współpracy na rzecz lokalnych rynków pracy doprowadziły do wysnucia przez autorkę wniosku, że struktury, których zadania ukierunkowane są na wspieranie lokalnych rynków pracy, odgrywają dużą rolę w tym zakresie. Małgorzata Malec pisząc o Wolontariacie jako przestrzeni uczenia się seniorów zauważa, że ta forma aktywności ludzi starszych jest w niewielkim stopniu rozpoznana w gerontologii. Wielowątkowa struktura tekstu zachęca w pierwszej części do refleksji nad teoretycznymi rozważaniami nad uczeniem się przez całe życie, aktywnym starzeniem się oraz różnymi formami wolontariatu w kontekście wieku. Druga część jest empiryczną ilustracją wolontariatu seniorów, w kontekście uczenia się i stanowi przyczynek do dalszych badań naukowych. Pierwszą część tomu zamykają teksty opisujące działania praktyczne, w których autorzy uczestniczyli lub które realizowali ze studentami. Katarzyna Uzar-Szcześniak w artykule Projekt międzypokoleniowy $w$ kształceniu geragogów i animatorów kultury, opisuje refleksyjną praktykę dydaktyczną i wynikające z niej wnioski. Autorka rozpoczyna od nakreślenia zbioru kompetencji koniecznych w pracy animatora/geragoga. Następnie omawia ramy koncepcyjne, organizacyjne i przebieg projektu międzygeneracyjnych spotkań realizowanych w ramach kształcenia uniwersyteckiego. Na podstawie informacji zwrotnych od studentów uczestniczących w projekcie, ukazuje efektywność w nabywaniu kompetencji animacyjnych. Kinga Majchrzak w tekście Gra miejska „Studenci UMK wobec miejsc (nie)pamięci”, opisuje interesujący pomysł gry miejskiej, mającej na celu uwrażliwienie studentów na miejsce, w którym przebywają, uczą się i którego są współtwórcami. Jarosław Dulęba przedstawia oryginalny projekt dydaktyczny wykorzystujący fotografię w integracji międzykulturowej i międzypokoleniowej oraz w animacji małej społeczności lokalnej.

Dyskurs poradoznawczy rozpoczyna artykuł Joanny Kłodkowskiej, zatytułowany Konstruktywistyczna perspektywa poradniczej rzeczywistości, opisujący wyłanianie się nowego modelu uprawiania poradnictwa, opartego na przyjętych przez poradoznawców założeniach konstruktywizmu społecznego i prezentujący nowe spojrzenie na teorię i praktykę poradnictwa z perspektywy konstruktywistycznej. Kolejny artykuł, niemieckiego badacza Clintona Enocha, Poradnictwo edukacyjne jako strategia komplementarna wobec koncepcji całożyciowego uczenia się, jest przeglądem i analizą zmian zachodzących w zakresie poradnictwa edukacyjnego oraz sporów i dyskusji toczących się w Niemczech wokół tej problematyki. Autor zauważa, że możliwości przystosowania się różnych form poradnictwa do przyszłych zadań będą zależeć od tego, w jakim stopniu uda się w sposób wiarygodny i celowy wpisać w daną ofertę poradniczą odpowiedzialność, solidarność i wspar- 
cie oraz przekonująco je wyrażać. Sukces poradnictwa będzie uzależniony od tego, czy będzie można z niego korzystać w sposób swobodny i czy będzie ono przynosiło efekty klientom i radzącym się. Małgorzata Rosalska w tekście Doradztwo akademickie w kontekście ksztattowania kapitału profesjonalnego studentów zastanawia się, czy i w jakim zakresie uczelnie mogą pomóc studentom w kształtowaniu ich kompetencji do funkcjonowania na rynku pracy. Autorka stawia pytanie: jakie kompetencje powinien posiadać absolwent uczelni wyższej, aby efektywnie planować i realizować ścieżkę własnej kariery zawodowej? Zagadnienie to przedstawia, odnosząc się do teoretycznych koncepcji dotyczących profesjonalizmu zawodowego, następnie wskazuje instytucjonalne możliwości kształtowania profesjonalnych postaw wśród studentów uczelni wyższych. Treść artykułu Marcina Szumigraja O potrzebie zmiany w kształceniu przyszłych doradców, przedstawia wstępne wnioski z prowadzonych w latach 2011 - 2012, wraz ze studentami Uniwersytetu Zielonogórskiego, badań nad funkcjonowaniem doradców zawodowych w roli zawodowej. Celem podjętych badań było poznanie postawy doradcy zawodowego wobec wykonywanej pracy. W prezentowanym artykule zostały poruszone dwie kwestie: współpracy i integracji środowisk doradców oraz działań doradców stanowiących odpowiedź na zgłaszane potrzeby klientów. W końcowej części artykułu zostały postawione tezy dotyczące zmian w sposobach kształcenia studentów w obszarach pracy społecznej, które być może ułatwią przyszłym praktykom realizację ich zadań zawodowych. Konkluzje $\mathrm{z}$ badań zawarte $\mathrm{w}$ artykule wzbogacone zostały o własne doświadczenia autora, wyniesione $\mathrm{z}$ pracy w zespole roboczym do spraw współpracy w zakresie realizacji poradnictwa i informacji zawodowej w województwie lubuskim. Dział ten kończy artykuł o charakterze metodycznym, autorstwa Joanny Dec, zatytułowany Specyfika doradztwa okołotestowego. Tekst opisuje specyfikę i praktykę poradnictwa towarzyszącego wykonaniu testu w kierunku HIV, zwanego poradnictwem okołotestowym. W artykule mowa jest o poradnictwie przed testem, jak i po nim, zasadach tego poradnictwa, jego warunkach oraz towarzyszących mu określonych procedurach. Autorka podejmuje także rozważania dotyczące ograniczeń owego poradnictwa oraz trudności, jakie mogą mu towarzyszyć zarówno po stronie pacjenta, jak i doradcy.

Dyskurs metodologiczny rozpoczyna artykuł Magdaleny Wojciechowskiej $O$ wyzwaniach w badaniu trudnych zjawisk. Metodologiczne aspekty badań terenowych na przykładzie zjawiska prostytucji kobiet. Badanie zjawisk trudnych angażuje badacza w proces nieustannego przezwyciężania kolejnych problemów pojawiających się w toku prowadzenia badań terenowych, które 
obejmują swym zasięgiem określone kwestie i trudności natury praktycznej, metodologicznej, jak i etycznej. Autorka sygnalizuje w swoim tekście problemy, które pojawiają się w tego typu projektach badawczych. Odnosząc się do określonych zagadnień dotyczących badań zjawisk trudnych, opisuje obszary realizowania projektów badawczych: badanie zjawisk trudno dostępnych dla badacza, prowadzenie badań w obszarze trudnego terenu (miejsc hermetycznych), zbieranie danych oparte na stosowaniu trudnych metod (przede wszystkim metod jakościowych), których wykorzystanie wiąże się z długim czasem przebywania badacza w terenie. Dokonując rekonstrukcji procesu badania zjawisk trudnych na przykładzie studium prostytucji kobiecej, autorka odwołuje się do problemu rzetelności i wiarygodności tego typu badań terenowych. W dalszej części artykułu, została poruszona problematyka związana ze specyfiką prowadzenia badań w obszarze trudno dostępnym, jakim jest świat agencji towarzyskich. Autorka opisuje założenia metodologiczne, które przyjęła. Wskazuje sposób kontaktowania się z rozmówcami i wyszukiwania agencji towarzyskich, w obrębie których prowadziła obserwacje. Tatiana Maciejewska w tekście Badanie zjawisk (nie)typowych-zastosowanie strategii jakościowej $w$ badaniu mężczyzn ćwiczących $w$ siłowni, odtwarza sposoby „bycia mężczyzną” przez mężczyzn ćwiczących w siłowniach: rozpoznanie postrzegania i kreowania przez nich tożsamości społeczno-kulturowej płci oraz opis działań podejmowanych w tym zakresie. Podjęta problematyka wymagała analizy nie tylko zachowań, ale przede wszystkim odczuć związanych z byciem mężczyzną we współczesnym świcie. Autorka zastosowała jakościową strategię badań i posłużyła się obserwacją oraz wywiadem narracyjnym, jako metodami gromadzenia danych. Marta Makowska w artykule zatytułowanym Prowadzenie wywiadów swobodnych na tematy drażliwe - przykład badań nad etyka pracy przedstawicieli medycznych przedstawia problematykę poruszania tematów drażliwych w wywiadach swobodnych. Autorka opisała kolejne kroki podejmowane w badaniach realizowanych z wykorzystaniem wywiadów swobodnych, na tle doświadczeń zdobytych w trakcie prowadzonych badań na temat etycznych standardów marketingu farmaceutycznego wśród przedstawicieli medycznych. W artykule przedstawione zostały problemy, przed jakimi stanęła badaczka podczas realizacji badania oraz sposoby, jakimi zostały one rozwiązane. Na końcu zaprezentowany został fragment raportu końcowego z analizy, gdzie przedstawiono wnioski dotyczące sposobów wykorzystania metod wywierania wpływu na lekarzy przez przedstawicieli medycznych. Trzeci dział rocznika zamyka tekst Katarzyny Kolbowskiej pt. Techniki jakościowe w badaniu środowiska niszowego. Grupy trenujacych Capoeirę - brazylijskq sztukę walki-tańca, w któ- 
rym znalazł się opis możliwości i ograniczeń w stosowaniu technik jakościowych w badaniu środowisk „niedostępnych”, które są hermetyczne i przez swoją tendencję do izolacji stanowią swoiste wyzwanie badawcze. Artykuł rozpoczyna się od spojrzenia na capoeirę jako kulturę alternatywną i wspólnotę estetyczną, dalej opisane zostały założenia metodologiczne, wybór technik, takich jak obserwacja uczestnicząca i wywiady swobodne. Analizie zostało poddane „ja” badacza jako jawnego obserwatora-uczestnika. Pod koniec artykułu autorka porusza kwestię wypracowanych w badaniu kategorii analitycznych.

Ostatnią część tomu stanowią sprawozdania będące relacją z ważnych dla młodych badaczy wydarzeń naukowych, takich jak: Letnia Szkoła Młodych Andragogów i Poradoznawców, Międzynarodowe Seminarium Cross Border "Career management skills", Naukowe Seminarium Poradoznawcze Horyzonty Pomagania.

Anna Matusiak, Agata Szwech 